で，過去10年間に経験した症例のうち，腹部外科領域の 疾患之誤診して開腹した症例，診断困難であつた症例に ついて検討し，鑑別の要点と治療上の問題を考察した.

1）急性骨盤内炎症。卵管资，卵管卵巣朖瘍及びその 破裂など 7 例を急性蛀资として開腹している。これら の症例では，腹部理学的所見中骨盤内診所見は鑑別上無 カであり，むしろ発症と月経周期，経過日数，熱型など が参考となつた。

2）卵巣腫㳻に起因するもの. 茥捻転及び破裂を各々 了例ずつ誤診している。破裂は茎捻転に続発したすの， 交通外傷によるるの，チョコレート衰庫破裂である。

3）卵巣出血. 6 例あり，亏ち4 例は急性虫垂炎,

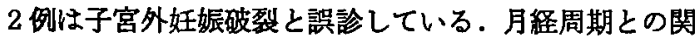
係，失血症候が参考となる。

4）子宮外妊㭛破裂、誤診は 1 例のみであるが，中絶 の出血を月経出血と誤認したことによる．

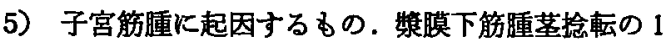
例がある. 子宮全剔街の必要な場合があり，麻醉や手技 上の問題が生じる。

6）その他. 稀な疾患として pyometra の穿孔による 沉発性腹膜炎の 1 例について, 文嗝的考察を加えた。

163. 急性間歇性ポルフィリアの1 例 八千代病院外科

佐藤太一郎, 七野 滋彦, 早川
船橋和
重喜, 宮本 佟, 半 佳之
橋 正文

本症は急激な腹部症状をすつて発症することから外科 領域では重要であるにも拘らず，稀な矤患の為に余り報 告されていない．また循謤系や呼吸の障害を伴らので麻 醉学の分野では最近, 注目されてきた. 最近, 私共は本 症の 1 例を経験したので報告し, 文献的考察を加兄る。

症例は34藏, 女. 美容師. 主訴注腹痛と腹部膨満感. 家族歷及び既往歴は特記すべきるのなし．

現病璴。昭和 49 年 7 月 25 日頃から腹痛があり, 腰部 痛，発熱を併発し，4日目に某病院一入院. その後も腹 痛, 腹部膨満感, 便秘が改善されず, 晹閉塞の疑いで 8 月 8 日, 当病院外科へ釈介された.

入院時所見. 顔貌中户苦閶状. 䧗部は平坦, 軟にして 蕒塊を触れ，压痛あり，腸雑音を聴取せず．検査により 貣血を認めす。，白血球增多と血沈の促進あり．肝機能挨 查では軽度の障害を認めた。䯣液検査で楉の軽度增量を 認め, 脳波で脳機能低下を認めた．注晹造影で大腸の拡 張を認めた。
経過. 入院後に全身疼孪あり. その後, 次第化上肢と 下肢の運動麻㾇が進行し，8月下旬には全く運動不能次 なつた。知覚は保たれていた．経過中バルビタール用の 使用によつて症状增悪し，赤色尿を見るに至つて本症の 診断を得た．PBG はしばしば陽性であつた１2月 2 日， 呼吸停止をみたので気管内㨉管し機械的人工呼吸を行な い，小康を得たが，結局53日目に死亡した。

剖検では神経系，殊飞末梢病変を認めた。

文献的考察. かが国では昭和43年までに 103例が報告 されたに過ぎなが，外科領域に於ても近時, 増加の值 向炕ある. 急性腹症としての本症, 本症患者の麻酶海 んでの注意, 及び本症患者の呼吸管理について文献的考 察を加光る。

164. 小腸良性腫瘍の 4 例 諏訪赤十字病院外科

寺島 文平, 杉山 正憲

渡辺 豊昭, 島田 寔

われわれは第36回の本学会において小晹癌の3 例を報 告（抄録のみ）したが，今回は最近 5 年間に経臨した小 腸の良性腫瘍 4 例を報告する。

症例 1 は46藏女性で大量の吐血, 下血で緊急入院し， 輸液・輸血などで状熊の改善を待ち，低㗨張性十二指腸 造影および十二指腸ファイハーースコープにて十二指腸良 性盾㴻と診断し手術を施行いたしました，組織学的には 平滑筋锤でした。

症例 2 は69才男珄で腹痛, 呕吐で来院晹閉塞症として 開腹した所, 空腸の良性遁漡による腸重積であつた。 組 韯学的炕血管瘇であつた。

症例 3 は48歳男子で腹痛, 呕吐があり䇣急入院し,シ ョック状態となり穿孔性腹膜炎と診断し開腹した所, 空 腸から管外性に発育した良性腫場の穿孔で，乙かも晹管 とは瘦孔で交通していた．組織学的には平滑筋瘇であう た.

症例 4 は 3 瓷の男児で, 腹痛, 呕吐, 血便で入院し 腸重積として開腹した所，回腸のポリープによる回腸一 回腸重積症であつた。組織学的にはすでに燷死におらい つていて判定不能であつたが，臨床的には明らがポリ ープであつた.

以上 4 例の小腸良性腫瑒を経験したが，症例 1 の十二

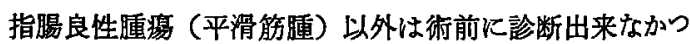
たが，若干の文献的考察を加え報告する.

165. 活動性回腸結核に回腸および回盲部の癌を阱存 した 1 症例について 
国立福岡中央病院外科

$\begin{array}{lrrr} & \begin{array}{l}\text { 松浦 } \\ \text { 龍二, 雷 }\end{array} & \text { 金溪 } \\ \text { 福岡市医師会病院 } & & \text { 尚一, 池尻 } & \text { 泰二 } \\ \text { 九大村 } & \text { 裕二 } \\ \text { 九第 } 2 \text { 病理 } & \text { 渡辺 } & \text { 英伸 }\end{array}$

私共は最近活動性腸結核と, 回腸および回盲部の 2 カ 所に癌を併存した症例を経験した。稀な症例であるとい らことに加えて，従来から言われているよらに，結核病 巣が癌の発生母地になり得るかと言らことや, 結核が免 疫学的な面から癌の進展に抑制的に働くかといらよう な，付随的な問題にも興味があり症例の大要を報告して 御批判を仰ぎたい。

症例は50藏の女性. 下腹部痛・膨満感および便秘を主 訴とし，胃腸透視の結果腸結核と診断され本院に入院し た.下腹部は軽度に膨隆し，右下腹部には腫瘤様抵抗を ふれ，腸雑音は六進している．臨床検查では中等度の貧 血があり，便潜血は強陽性・トリブレ反応も陽性・血沈 は 1 時間 $25 \mathrm{~mm} \sim 2$ 時間 $57 \mathrm{~mm}$ ・ツ反応陽性・胸写では右肺 尖と左下野に石灰化像あり・程口小腸透視では下部小腸 に2 カ所の㹟窄と拡張があり，回腸末端から盲腸にかけ ての変形狭窄がある.イレウス症状のため開腹. 病変は トライッ靶帯より $2 \mathrm{~m}$ の部と $2.5 \mathrm{~m}$ の部分の腸管に輪状 狭窄があり，狭窄部より口側の腸管の㧓張が認められ た.また回盲弁より口側 $20 \mathrm{~cm}$ 部分と回盲部にそれぞれ 手拳大の尰瘤 が存在し, 周囲と線維素性に癒着してい た. 狭窄部を含む回腸と回盲部切除を行ない，創は一期 的に澺合し退院した。切除回腸は中心部に乾酪壤死を伴 ら活動性腸結核がみられ，また回腸と回盲部の 2 腄瘤は 粘液分泌を伴ら高分化腺癌がみられた。回腸の癌病巣中 の表層部や，深部浸潤最先端部には乾酪壊死を伴う結核 結節が喼められた，癌と結核が併存する場合には細胞性 免疫が増強するといわれているが，本症例では癌周囲に リンパ球の著明な増生はみられなかつた．腸結核と腸癌 の併存はまれであり, 癌と結核との相関関保についてむ 興味ある問題が提起されている折柄御報告申し上げる。

166. 小腸腫瘍の臨床的考察一特に小腸癌を中心とし $\tau-$

東北大学第 1 外科

$$
\begin{aligned}
& \text { 并上 進, 佐久間 晃, 早川 勝 } \\
& \text { 熊本 基, 佐藤 寿雄 }
\end{aligned}
$$

東北大学第 1 外科飞怙いて，昭和 36 年 4 月より昭和50 年6月までに手術で確かめられた原発珄小腸腯場は十二 指腸乳頭部癌を除き24例である。その内訳は十二指腸て
は癌腫 2 例, 肉腫 4 例，ポリープ 5 例であり，空腸回腸 では癌腫 3 例，肉腫 5 例，ポリープ 2 例，筋腫，神経䩗 畽, 脂肪腫が各 1 例であつた，小腸腫演を良性悪性に分 けて年令, 性をみると, 良性悪性共比男子に多い傾向が みられ，年令別では良性例は40代を中心とする比較的若 年者に多く，悪性例は60代を中心とする老年者に多くみ られた。臨床症状を腫湯存在部位別に検討すると，十二 指腸の悪性例では，6 例中 4 例に尰瘤触知，呕吐が認め られたが，良性例ではほとんど自覚症状は認められなか つた. 空腸回腸腫瘍では良性例でも症状が比較的多く, 5 例中呕吐 3 例, 腫瘤触知 1 例が認められた. 悪性例で は，8例中 5 例に下腹部痛， 3 例に尰瘤触知，呕吐が認 わられた. 小腸尰寡の診断適中率をみると，十二指腸悪 性 6 例では術前診断が適中したのは癌腫 2 例のみであ り, 尰湯が大きくなり肝腫瘍, 後腹膜腫痬との鑑別が困 難であつた 2 症例もみられた。 十二指腸良性例では全例 術前診断はポリープと形熊学的な診断しかつけられず, 肉芽腫，血管腫など質的診断は困難であつた．空腸回腸 良性例では術前診断は，5例中 3 例が腸重積で緊急手術 を施行した症例であり，先進部となつた腫瘍は腺腫性ポ リープ, 神経鞘腫, 平滑筋腫であつた. 空晹回腸悪性例 では術前診断は多種多様であり，8例中 1 例のみが小腸 連潪と猃断し得たに過ぎなかつた。

今回は小腸癌を中心として小腸連瘍について盬床的考 察を加えた結果について報告する。

167. 原発性空腸癌の 2 例 鹿児島大学第 1 外科 船迫 進, 筄原 浩, 野村 秀洋 西瀬戸紀征,川進浩, 阿久根 務 加治佐 隆, 西 満正 鹿児島大学第 2 内科

種子田郎, 有馬 貞三

原発性空腸癌は極めて稀な疾患である，我々は術前に $\mathbf{X}$ 線診断，小腸ファイバースューブ执よび生検にて空腸 癌と診断し，切除した 2 症例を経験したので文献的考察 を加えて報告する。

症例1.39歳古, 主訴呕吐, 病脳期間 2.5 力, 腸透 視で不規則な陰影欠損と狭寉像がみられ，小晹フォイハ ースコープにて悪性所見を確認して空腸癌と診断し手術 を行なつた．空腸起始部にほぼ鵎卵大の墏膜浸潤を伴な ら尰瘤があり，肝右葉への転移及び下腸間膜静脈根部り ンパ節への転移と周囲組織への浸潤著しいため姑息的空 腸切除を行つた。切除標本では2.3×2.3cmの Borrmann 
III型, poorly differenciated adenocarcinoma $\left(s_{2}\right.$ INF- $\gamma$ ) であつた．術後 FAM 療法を行らも副作用出現のため中 止し, 術後23日で軽快退院したが 4 カ月後に肝転移增悪 により死亡゙した。

症例2. 55歳古, 主訴呕吐, 病恼期間 2 力月, 腸透 視で陰影欠損と狭窄像を認め, 小腸ファイバースュー プで悪性溃瘁を確認し，生検にて poorly differenciated adenocarcinoma の診断を得て手衍を行つた. Treiz 鞂带 より $30 \mathrm{~cm}$ 肛門側に獎膜浸潤を伴ら腫瘤があり, 腹腔内に 広汎な播種性転移がみられたため姑息的空腸切除を行つ た. 切除標本では2.5×2.5cmの Borrmann III型, poorly differenciated adenocarcinoma $\left(s_{2}\right.$ INF- $\left.\gamma\right)$ の病理診断 であつた。術後 MFC 療法を行らす副作用出現のため中 止し, 術後59日目に軽快退院したが 6 力月後の現在腹水 の貯溜を羿める。

168. 十二指腸 Vater 乳頭部及びその附近に発生し た乳頭涯の 1 例について

東邦大学第 3 外科

松本 光, 門松 拓郎, 小島 京介

横山 隆唗, 鶴見 清彦

東邦大学病理 秋間 道夫

十二指腸良性腫㶼は極めてまれなるのであるが，全小 腸腫瘍の約20〜30\%を占める. その好発部位は十二指腸 上部が最も多い. 組織学的分類から乳頭腫を含めて腺腫 の頻度が高い，我々は最近遗残結石及び十二指腸 vater 乳頭部より発生した有茥性乳頭腫の手術をらけ， 4 年後 に十二指腸下行脚に 2 個の乳頭腫が発生した症例を経験 したので若干の文献的考察を加えて報告する。

症例：64藏男子. 昭和45年11月胆石の手術をうけた。 退院後時おり発熱を生じた. 黄㡺は認めないが呕気, 右 季肋部痛を訴党, 頻繁に発熱するよらになつた。背脈性 胆道造影にて 総胆管に连残結石を認めた．昭和 46 年 6 月, 十二指腸上部総胆管切開術にて結石を摘出したあ と, 十二指腸を切開して検索すると, Vater 乳頭部より 発生したウズラ卯大の有茥性腫瘤を認めた。その表面は カリフラワー状であつた，良性腫湟摘出術及び乳頭形成 術を併用した。手術経過良好にて退院した，組織学的所 見は乳頭状増殖する腺上皮からなる有茎珄乳頭腫で一 部活動性增殖を認めた．患者はその後数年の間，頻回に 晹閉塞症状を呈したが，保存的治療にて軽快していた。 昭和49年12月再び発熱, 呕吐, 下腹部痛を訴え入院. 次 第に黄㾝, 貧血が増強し, 弛張熱が出現して来た.十二 指腸内視鏡にて，十二指腸下行脚内側にウズラ卵大の隀
瘤を認め，その表面はカリフラワー状で易出血性であっ

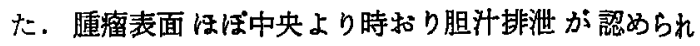
た。この腫瘤に近接した口側十二指腸粘膜に母指頭大の 腫瘤が見られた. 昭和50年5月21日に乳頭腫切除術を行 つた. 組織学的所見では, 双方とるパネート胞細を含む 高度に分化した腺增殖からなる乳頭腫で一部翼型化を㒛 めた. 術後一時吐血, 下血を認めたが順調な経過をたど つた.

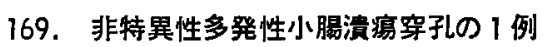
富士原病院 柴田 族光, 富士原正保 空腸に発生した非特異性多発性小腸潰痦穿孔例を経臥 したので報告する.

50歳男性. 約 2 週間前より発熱, 右季肋部痛を訴克,

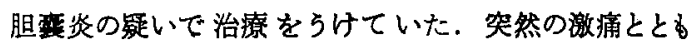
に, 汎発性腹膜资の症状で来院した. 立位腹部単純撮影 にて, 右横隔膜下に遊離ガス像を認め, 緊急手術を施行 した.

既往憷には11年前胃潰湢で胃切をらけている。

吻合部潰痬穿孔を整い開腹した。しかし，残胃灾よび 吻合部には異常を認めず，また十二指腸にす異常所見を 認めない，右側腹部小腸が炎症性に痹着し，物合線から 約 $2 \mathrm{~m}$ 肛門側小腸に，あたかも十二指腸潰場穿孔のこと くにみえる直径約 $1 \mathrm{~cm}$ の円形穿孔を認める．腹膜炎のた め小腸全体は浮尰を呈しているが, 触診上, 回腸末端京 でに異常硬結などは触れない.

切除標本をみると，4個の辺縁整なる大小の潰掦があ り，そのらち 1 個の溃珤中央部で穿孔していた。

病理組織学的には非特異性多発性小腸潰瘍である。

小腸潰婸は稀な疾患であり，むた術前診断は非常に困 難である，非特異性潰瘍とは結核，梅毒なと潰瘍の原因 と思われる病理学的所見が譛められないとき用いられて

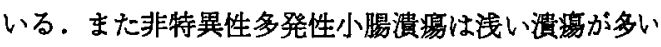
が，われわれは穿孔した 1 例を経鈳したので報告する.

170. そけいヘルニア患者に発生した小腸穿孔の2 例 徳島県立中央病院外科

$$
\begin{array}{ll}
\text { 大塚 康吉, 長野 貴 } \\
\text { 林 尚彦, 藤原 晴夫 }
\end{array}
$$

最近 2 年半の間に経験した小腸穿孔は13例で，外倩 5

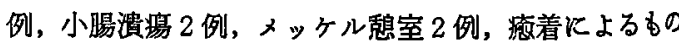
2 例，ステロイド潰场 1 例，悪性リンパ属 1 例である. このらち2 例はそけいルルニア患者発生しており，そ けいヘルニアの合併症とる考克られる。13例を検討し， ヘルニア患者例を中心に報告し考察を加える. 
症例1.76踒，男. 以前より左そけいヘルニアがある が健康であつた。畑仕事中に牛鿓をふみ，足がすぺつて 転倒した．倒れた所は平坦な畑で，石や器具などなかつ た.その後，腹痛があるので近医を受診し，腹痛が次第 に増強したため当科へ紹介された．来院時，血圧は 2190 ， 腹部は全体に板状硬で压痛が著しい，白血球増多はな く，腹部レ線像で遊離ガスは認められなかつた，沉発性 腹膜炎の診断のもとに直ちに開腹術を施行した．膿性腹 水多量に流出し，回腸末端より70 cmの部に穿孔を認めた のでこれを秚合しドレーンを㨉入した，術後経過は良好 で 4 週間後に左内そけいールニア根治術を施行した。

症例2. 59歳, 男. 精神分裂症で某精神病院へ入院中 の患者で，しばしば右そけいルルニフの嵌屯をおこし徒 手整復していた，半年前に当科でそけいいルニア根治術 の予定であつたが，本人が拒否し中止したことがある. 昼食後, 突然ショック状態となり, 輸液特よびステロイ ド注射を行ない当科へ稆介された，来院時の血圧 $\%$ 。 腹部全体汳状硬で下腹部に圧痛が著しい，白血球增加 はなく，レ線像で腹部に遊離ガス像は認められなかつ た. 汎発性腹膜炎の診断で開腹したところ, 回腸末端よ り $130 \mathrm{~cm}$ 部で回腸の一部が限局して複雑に瘾着し一塊 となり， 2 カ所で穿孔している．腸切除後，端々吻合 し，腹胎内より内そけい輪を䋖合閉鎖しドレーンを挿 入して腹壁を閉鎖した. 術後 1 カ月目に治痊退院した。

171. Grynfelt ヘルニアを合併した空腸多発性䕀室 定の 1 例

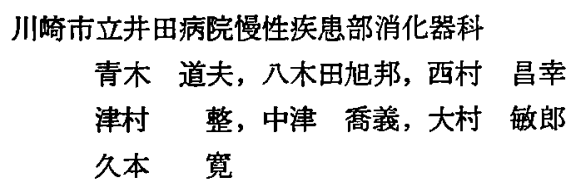

最近多発性空腸稳室の報告例をみることが少なくない か，多発性空腸秝室に比較的稀な Grynfelt ヘルニアを 合併した症例を経験したので報告する．

患者は65歳男性. 既往歴には30歳に陽チフス，40歳に 右䋃径へルニア根治術．家族歷には特記すべき事なし． 約 8 年前より左季肋部胁骨弓下縁より脐に向けて索状で 有痛性かつ易還納の膨隆に気ついている. 又, 昨年夏頃 より摄食後の心简部痛および上腹部違和感が出現してき た. X線透視等により空腸多発性想室及び左上腰部へル ニアと診断され手術の為入院となる.

入院時所見は体格やや小で貧血認めず.心简部圧痛軽 度以外特記すべき事なく, 血液, 生化学的検查にる異常 を認めない. 便潜血 (一). 上部消化管 $\mathrm{X}$ 線写真にて十二
指腸憩室及び 6 個の空晹䄭室を認める．腰部へルニア門 敕縮術及び空腸切除術を行い，術後経過は良好で以後主 訴は楥解している。

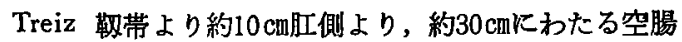
腸間膜附着部に近い部位に大小 6 個の空晹䕀室を認め た. 病理学的には彭室粘膜の肥厚，毛細血管怒張及びう つ血, 筋層欠如, 想室周囲にも軽度の炎症等 が存在す る.

空腸唕室としては現在迄 100余例の報告と比較して, よく特㣲的に類似するが，1866年 J. Grynfelt (仏)の 報告以来の比較的稀な上腰部へルニア及び十二指腸礊室 を合併し，さらに右巣径へルニアの既往歴を有している 事なとが特異的である.これら相互の関連性, 特に先天 及び後天珄, 葴器及び解剖学的関係について興味ある症 例であり，若干の文献的考察を加劣て報告する．

172. 術後腸麻疸に関する検討 東京慈恵会医科大学第 2 外科

河野 勝䮶，長尾 房大

術後腸運動麻愺は, 術後の患者の経口摄取の時期を左 右するのみか，直接患者の回復をる左右する問題であ る.

我々は，腸運動に関与すると考えられる諸因子につい て来験的に検討して来た．今回は，教室で過去 5 年間に わたつて経験しえた 233症例について，いわゆる術後腸 麻症期間に関して検討を加えた，対象は，胃潰瘍78例， 十二指腸潰瘍69例，胃癌86例である，検索項目は，性 別, 出血量, 疾患別, 手術術式, 手術時間, 年令別等で ある。

成績は，性別および出血量と，腸麻瘏期間との間には 全く関係が認められなかつた．矮患別では，良性疾患之 悪性疾患とでは，腸麻瘏期間はそれぞれ平均53.9時間， 57.9時間であり，大きな差違は認められなかつたが，悪 性疢患群の方が腸運動開始時間に疾患別のばらつきが多 く認められた。手術術式別では，ビルロートI法で平均 60.85時間, ビルロート II 法で平均 59.00時間, 近位撰 迷切術で平均 47.80 時間であり, 近位撰迷切術群の方が 胃切群にくらべ腸麻疸期間は短かつた，手術時間別で は, 1 時間以内群は平均 19.33 時間, $1 \sim 2$ 時間群は平 均 52.74時間，2 時間以上群は平均 52.95 時間であつ た. 年令別では，20歳以前は平均19.3時間と腸麻疩期間 は短かつたが，30代，40代，50代，60代以上の間にはほ とんど差違が認められず，約55時間前後であつた．結 局，術後腸麻疩の長短を左右する因子は多々あると考点 
られるが，今回の調查では，手術時間，とくに 1 時間以 上の腸麻㥏が長い事, また街式では, 胃切と近位撰迷切 との間には大きく差があつて, 胃切群の方が腸麻瘁期間 が長い事がわかつた。

173. 所謂 “非特異性多発性小腸漬瘍症” の 1 手術例 鳥取大学第 1 外科

$\begin{array}{lrrr} & \text { 中尾 } & \text { 実, 喜安 } & \text { 佳人 } \\ \text { 田村 } & \text { 英明, 安達 } & \text { 秀雄 } \\ \text { 同第 } 2 \text { 内科 } & & \text { 三好 } & \text { 洋二 } \\ \text { 日立安来病院内科 菅野 } & \text { 誠司, 麦谷 } & \text { 碧 }\end{array}$

最近，小腸飞多発する非特異性の極的て浅い溑晹性 病変を呈し，しかすCrohn 氏病飞代表される regional jejunoileitis とはかなり異つた臨床病理像を是する疾患 一非特異性多発性小腸潰嗱症一があることが注目されて いる. 本症の成因はいまた不明であるが，現時点では外 科的治療を要する新しい概念の小腸疾患であると考劣ら れる。

最近，私達はレ線的核䉼しえた本症の 1 手術例を経 験したので，若干の文献的考察を加えて報告する.

症例は27歳, 男, 無職, 主訴は著明な貧血と腹痛, 3 歳時小児麻疩に䍜患した際, 貧血と発育障害を指摘され る. 以後, 日常生活困難で対症療法のみをくり返しなが ら現在にいたる．27藏時, 当院にてレ線的に下部小腸に 多数の輪状狭窄所見を毠見したため本症を疑つた．主な 検查では賀血および低蛋白血症著明, 便潜血反応は常に 持続性陽性, ツ反応 (一) であつた。 手術所見は, 回盲

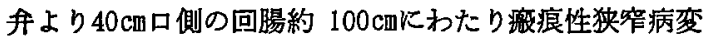
あり.切除標本では10個の極めて浅い不規則な腸管をほ ば輪走する潰愓性病変を認めた。病理組織学的にはUI II 主病変とする非特異性の炎症像を呈し，いわゆる fibrosis ஓ granuloma 等の形成は認められなかつた.こ れらの病理組織学的所見は regional jejunoileitis とはか なり相違して㧍り，岡部らが呼称する小腸の nonspecific multiple ulcers の criteria にはいる小腸疾患と考克られ る. 本症はまだ末解決の問題が多く残されている点よ り,さらに本症例の術前術後の経過を詳細に検討するつ ๖りである.

174. 多発性非特異性小腸清瘍の 3 症例 佼成病院外科

松林冨士男, 小金沢 满，传藤 蕉隆 野々部泰彦，林文良，李嫃一 山西宏佳, 䥡田 直司, 清水 雅樹

本症は低蛋白血症，貣血，下血などで，レ線検查をう
け小腸に異常所見が見い出されたり、イレウスなと緊急 開腹時偶然発見されるような場合が多い，最近では本症 㳊関する報告む多くなり，臨床的，病理学的特徽むかな り詳細炕あげられているが，まだそれはどポヒニラーな 疾患ではない。またその本態す明らかでなく，発生部位 る小腸といらことで，診断はなかなか困難である。

以上の上らな理由で我々外科医は今後いるいろな形で 本症に遭遇することになるであろら，最近我々る本症 の 3 症例を経験し，各タ異なつた形で誩断され，手行さ れ，その結果本症であることを確定したるのである.

症例 $1: 65$ 歳女. 下痢, 腹痛, 腹部㵙満感で入院. 椧 查の結果, 貧血・低蛋白血症が認められ，レ線検查の結 果回腸に数力所の狭窄部位あり. ${ }^{131}$ IPVP の瓷中排渵で 高値を示し, 蛋白漏出性腸症と訩断し, この部位の回腸 切除を行つた。症例 $2: 45$ 藏女. 3 年ほど前より全身院 怠感あり，内科受診の結果 $\mathrm{Fe}$ 欠乏性䅡血を指摘されて いた．胃腸管よりの出血は考光られていたが，その出血 源を発見できず，たんに対症療法のみ行つていた．そこ で我ヶのところで行つている消化管出血部位判定チュー ブルよる検查を依頼されてきた. 明らか汇回腸に出血源 があることを診断した，手術を行い，該部の切除を行っ た. 症例 $3: 30$ 歳男, 約 3 年前より時々下腹部痛あり, そのつど対症療法をうけていた。.今回は腹痛がいつるよ り強く，呕吐を伴つたので，本外科に紹介されてきた。 小腸イレゥスの診断で開腹し、イレウスは本症によるる のであることが解つた。

切除標本より 3 例とも同一の性質を有し，肉腿的飞も 粗織学的にも岡部等の述へている如く限局性腸炎とも， 孤立性小腸㵋瘍とも全く別個のものであると考兄られ た。

175. 教室におけるクローン病 5 例について 千葉大学第 2 外科

斉藤登喜男, 佐藤 博, 穖野 可一 传藤 裕俊, 小池 良夫, 小野田昌一 奥山 和明, 植松 貞夫

1965年より，1975年までの11年間に，千葉大学第 2 外 科江於て，大腸切除術を施行した症例は，155例である。 この内訳けをみると，大腸癌 140例大腸ポリーブ，また はポリポージス 7 例, クローン病 5 例（回腸末端部の症 例を含む)，その他 3 例となつており，大腸癌の占める割 合は, $90.3 \%$ と最む多く，クローン病は，全体の $3.2 \%$ となつている.今回は，このクローン病 5 例炕つき報告 する. 
まず臨床症状よりみると，腹部腫瘤は，全例に認めら れるい湄は，4侧に，また下㢉，発熱は夫々 3 例に認 められた．既往歴よりみると，5例中 4 例に虫垂切除術 の既往があり，特にこのらち 1 例は，術後イレウスにて 2 回開腹術を受けている.一方虫垂切除術を施行してい ない1例は，6年前に回盲部腫瘤の診断のもとに，回盲 部切除術を施行している.

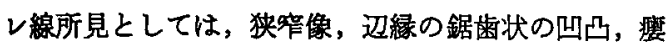
孔等を認めるが，特に小腸との間に瘦孔を形成した症例 が1例に怹められた. 術式よりみると, 回盲部切除術 3 例吻合部再切除術 1 例, 大腸覀全剔出術兼小腸切除術 1 例となつている.特にこの症例は，横行結腸と，Treitz 勒帯より $5 \mathrm{~cm}$ の部の小腸との間に瘦孔を形成し，この部 の小腸切除術白合せて施行している。

次に，肉眼所見よりみると，まずその病変部が回盲部 に限局する症例は 2 例，回腸末端部（吻合部の小腸む含 も）2例，また回腸より結腸に及ぶ症例 1 例となつてい る.また病変部が非連続的に存在する症例は，3例であ つた. 粘膜面には, 潰煌形成, 教石状病変, 裂暳形成等 が認められる．以上クローン病につき報告し，合せて文 献的考察を加觉る。

176. 小腸大量切除 4 例の踟床病理学的検討 国立金沢病院外科

森田 弘之, 高松 脩, 津田 客信
浅井 伴衛, 磨伊 正義, 正来 恭定
今井 武司, 中田 理, 道場昭太郎
神村 盛宜

小腸広範囲切除の定義についてはあいまいで，全小腸 の $1 / 3$ 以上の切除について言うこともあり， $\%$ 以上とする あのああるか，一般的に $1 / 2$ 以上の切除を行なら場合と解 釈されている.最近我々は 4 例の大量切除例を経験した が，いずれる以前に開腹手術を受けており，一例は何回 もの手術の結果 ${ }^{1} / 2$ 切除となつている．4 例共に原因はゆ 着性イレウスまたは同時に存在するBlind loop のためで ある. 病理所見としては腸管相互のゆ着が著明で，壁は 浮腫状となり，腸管の払張，漿膜面の白苔附着等が認め られ，組織学的には Bionecrosis の状態のるの», Blind loop K多発性潰瘍等が認められた。臨床経過は1/2切除 にとどまつた 2 例は Short bowel syndrom はそれ程著明 でなく，最る多く切除が行なわれた 2 例を中心に報告す る. 2 例はそれぞれ空腸の $120 \mathrm{~cm}$ を残して大量切除が行なわれた。術後は 2 例共には注順 調な経過をたどつたが，Pullan の言51期では下痢，
放屁頻数，口渴等を認めたが，著明な電解質のアンバラ ンスはなく,カロリー源として，イントラリピド, MCT 投与等を行なつた．第 2 期に入ると，下浰症状は改普さ れ，次第に体重増加を示したが，なお著明な脂肪吸収障 害が認められた。軽度の味覚, 臭覚の異常や関節痛を訴 えたが，他に重篤な自覚症状はなく，整作業に従事し得 るまでに回復した．術後レ線検査ではバリウムは 1 時間 で横行結腸まで達し，胃液は分泌過多曲線を示した。そ の他の検査です肝機能不全，貧血は見られなかつた。以 上を文献的考察を加えて報告する。

177. 腹部外科臨床における結核症の 7 例 済生会八幡病院外科

村上 博固，松田哲之輔，力丸 健 綾部 欣司

九州崡科大学外科

草場威棱夫

昭和 45 年 5 月, 济生会八幡病院・外科に, 大腸肛門部 （医長：村上博图）が附設された. 以来，今日までに， 大腸 X線検查が 1,849例, 小腸 X線検查が 360 例, 直 腸・結腸内視鏡検查が 600例に実施されている。

また，この期間の大腸・肛門部に関連した手衍症例は 300例で，らち7例が結核症例である。

その診断過程をみた場合, 術前診断後開腹症例は 2 例 で，他は，晹瘦造設術後診断症例が 1 例, 試験開腹術後 診断症例が 2 例, 贀急開腹術後診断症例が 1 例, 痔瘦切 開術後診断症例が 1 例などで, 術前確診の困難性が痛感 された。

今回は, 以上 7 症例の概要を述べ, 外科臨床上の問題 点について, 考察を加充報告する.ことに, いわゆる急 性腹症で外科的治療を要した次の症例を示説し, 詳述い たしたい.

（淀例 1 ）33歳, 男. 昭和47年 1 月 21 日手術例. 結核 性回腸潰瘍穿孔による急性腹膜炎症例。

（症例 2 ） 22 歳, 男. 昭和 47 年 7 月 4 日手術例. 空 腸・S 字状結腸に括ける結核性漬瘍の被椱性穿孔症例.

(症例 3) 30歳, 女. 昭和49年10月29日手術例. 寸で に，数年来，関節ロイマチスムスの診断の下に，内科的 療法として，副腎皮質ホルモンなどが投与されていた。 この度, 回盲部に潰瘍形成がみられ，その質的䛦断の過 程で，イレウス症状を呈し開腹した所，空腸・回腸およ び盲腸に多発した結核性溃湟が認められた。

(症例 4) 56藏, 女. 昭和50年 1 月22日手術例. イレ ウス症状で腸瘦造設時に結核性腹膜炎がみられた。

上記症例の他に, 一般外科部門でみられた. 若干の症 
例をも追加供臨し，慢性的な腹部愁訴之腹部外科に括け る結核症とについても，附言いたしたい所存である。

\section{8. 悪性黑色缠転移によるイレゥス経駼例}

久留米聖マリア病院外科

古賀 昭次, 三好 敦生，堀 英晴

赤岩 正夫, 広橋 貫之

我々は最近悪性黒色重の一例を経験した。

症例は62歳の男子でイレウス症状を主訴として来院. 肺転移を伴ら悪性腫瘍によるイレウスの診断で手衍施 行, 開腹により悪性黑色腫の小腸及び腸間膜リンパ節転 移によるものと判明した．術後の检索で原発笨は左足底 部の皮下にクルミ大の結節型畽演を認めた。これは患者 自身が約30年前よりその存在を自覚していた。この症例 は術前より肺転移も認ぬられたので原発巣の摘出は行わ ず抗癌㓮の多剩大量投与を行い現在何等自覚症状なく社 会復帰している．悪性黒色腫はクラーク等によると，1) 結節型黒色腫，2） 悪性黒子型黒色瘇，3） 表在型黒 色腫の 3 つの型に分類される. 又, リンパ節，内臟器に 転移を生し，下肢，趾，足底，顔面等飞好発し，男子に 多く，予後は不良である.白人に多く，次いで黄色人種 で，黒人にはきわめて稀である．色素母斑，黒子が発生 母地となり，外傷，慢性の機械的刺激により発生する。 治療として, 厷沉な切除、リンバ節摘出, 大量のレ線照 射，抗癌郕投与を行う．以上わが国では稀な症例を経験 したので報告する。

179. 子宮癌及び直腸癌に対する放射線照射後に起っ た小腸閉塞症の臨床像について

大阪医科大学第 1 外科

冨士原 彰, 宮地 道弘, 宮宗 慎吾
宮本 学, 宮地 吉弘, 生田 邦夫
安井 広明

放射線照射による胃腸管の障害は Walsh（1897）によ り初めて報告され，1907年 Krause, Ziegler 等は小腸粘 膜がその影響を受けやすいととを証明した。特に子宮癌 の放射線治療において，瞵接喴器である膀腅，直腸は影 響を受けやすく，重篤な合併症を起すことはまれではな く，数多くの報告がみられる.

我々は最近経験した小腸閉塞症例に子宮癌，直腸癌の 後療法として過去 1 3 年飞 $\mathrm{CO}$ 照射を受けた既応があ り，開腹時局所再発はなく，閉塞の原因が原疾患ではな く，放射線障害と考光られるるのを経験し，その臨床経 過炇て，放射線照射を全く受けないるのと飞差がみら れることを知つた。照射症例に外科的処置を行つた場合
術後释合不全を起し腸瘦を形成したり，急激に死の転㫶 をとるケースが多い，過去我々が経験した子宮瘊及び直 晹癌術後湯閉塞を起し開腹, 原因が癌の再発によるる のでなかつた 9 症例沈ついて，術後の䠛床経過，衍後合 垪症発生及び予後と，照射量との関係等について検討を 行つた。

年令では30歳代， 4 例. 40 歳代， 3 例. 50 歳代， 2 例，発生までの期間は照射後 1 年に発生したるの 4 例， 2 年； 3 例， 3 年 2 例で共飞照射量との間飞明らかな相 関はみられなかつた。. 他の婦人科手衍後の腸閉塞と比酸 すると全治した症例でる，術後創治瘭が暒延し，臨床経 過が長いものが多い，死亡例 3 例では, いずれも初回手 術後CO 照射を受け，1 年以内に再発の診断で再度照的 を受けて招り，1回照射例に比へ，縫合不全により死亡 している. 術後照射がその後に惹起された閉塞症の予後 に大きな影響を与えること，特に 2 回照射症例ではその 危険が大きいことを強調したい．

180. 腸開塞の原因となった回腸エンドメリオーシス の 1 例

\section{東京齿科大学外科 \\ 酒井 忠昭, 宮崎 道夫, 田中 豊治 池田 武彦, 小野 成夫, 加藤 繁次}

異所性エンドィトリオーシスは子宮, 卵管, 卵巣等女 珄の骨盤内䐵器及び腸管比生ずるほか，稀飞肺，胸膜に

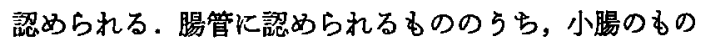
はきわめて稀であり、しばしば mass に上る陽閉塞状態 をきたし，小腸の悪性新生物との鑑別が臨床上問題とな ろ.

症例任38藏，既婚の主㷌で，約 3 年前から生理期飞一 致した腹痛，呕吐，下浰を認めていた。婦人科医を受診 乙月経困難症と診断され黄体ホルモンの投与をうけ，症 状軽減していたが，昭和50年 1 月腸閉塞状熊をきた，

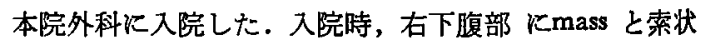
物を触れ，腹部レ線写真飞鏡面形成を認めた。貧血，白 血球增多，低蛋白血獎はなく，血清電解質，肝機能倹查 の諸項目は正常域にあつたが，便潜血はグアヤック(士) であつた，腸管エンドメトリオーシスを強く疑い，開腹 街を行つた. 回腸末端部より口側約 $10 \mathrm{~cm}$ に示指頭大の mass を認め，小腸はこれを中心液痕狭窄を呈すと同 時治く屈曲して和り，口側腸管は著明江掺して通過 障害が認められた，子宮は前方で䧛胀と㴰着しており， 附近に 粟粒大の出血斑を多数認め, 子宮内膜の骨船㬺 implant と考えられた。術中小晹狭窄部近傍のリンバ節 
の凍結標本に悪性所見はなく，回腸エンドメトリオーシ スと診断し回宣部切除を行つた。病理組織学的に, mass 飞一致して墏膜から㬳層にわたる子宮内膜腺が認められ エンドメトリオーシスと診断された。その後患者は術前 の症状から全く解放された，本症は術前しばしば急性虫 垂炎と診断されることが多く，開腹時の状態は小腸悪性 新生物との鑑別が問題となる。般に，比較的経過の長 い生理期に関連した消化器症状を認め，一般状態は良く 保たれていて多くは便潜血陰性を示すが，手術に際し凍 結標本による猃断が是非必要である。

181. 食触による腸閉塞症の 4 例

名古屋保健街生大学外科

吉崎 聭, 山田 好則, 佐々木哲二
丸田 守人, 船电 孝彦, 守谷 孝夫
青木 春夫.

食慨による腸閉塞症は本邦に於いて 200例余の報告が みられるが，その約60\%は柿に起因していると言われて いる.我々は最近ニンブの根を摂取した後に腸閉塞とな り，遂に穿孔性腹膜炎を著起した症例を経験したので， 過去の食慨性イレウス 3 例と併せて報告し，内外の文献 的考察を行なつた。

症例は56歳の男子で，昭和50年 1 月 6 日夕食後に突然 の腹痛を来たし，近医にて鎮痛肪の投与を受けていた か，次第に疼痛增強したため 1 月 8 日早朝来院した。初 診時顔面套白，苦閵状で，呕気呕吐著明，胸部には異常 所見なし，腹部は全体に板状硬で，グル音は聴取出来な かつた. 排気排便は停止していた，既往症として，10年 前左股部の肉腫にてコン゙ルト照射を受けて居り，下腹部 皮庙江広沉な放射線湤痕を認めた。倹查成績では白血球 数13,000以外には殆んぞ正常值を示していた。そこで陳 旧性放射線漬湯の穿孔性腹膜炎ではないかと考えて，緊 急手術を行なつたところトライッ勒帯より 130 精肛門 側に, 約 2 锂 $\times 3$ mmの穿孔を認め, 周田に膿瘍を形成し ていた. 穿孔部には硬い腫癌をられるため。これを含め て約20cmの腸岈除を行なつた．術後経過は良好で， 3 週 間目に退院した. 切除腸管の内容は三角形のコンプの根 で，ほとんど消化されていないために，その鋭角の部分 が穿孔の原因になつたと考光られる. 本例の他に，豆モ ヤシを洋血一杯摂取してイレウスとなり，開腹して腸内 容を結腸に迄㵠出した 1 例，及びヌンニャク，シラタ キを大量摄取してイレウスとなつた 2 例を経験している が，後者は胃切除後に発症した例であり，幽門機能を持 たないことに本症の原因の一つを求めている内外の文献
が多かつた。

182. 結腸・直腸癌によるイレウスについての検討 東京都立墨東病院外科

渡辺 千之, 山岡 郁雄, 松桻 敬夫

浜田 節雄, 金子 博, 浮島 化也

結腸・直腸癌では，出血，閉塞，穿孔が重大な合併症 を引き起す症状として重視されている。我及は都立墨東 病院外科に沶いて昭和38年より昭和48年までの11年間に 42例の結腸・直腸癌に起因するイレウスを経験したので 検討を加えた。

この期間の全症例は 12,061 例あり，ちちイレウス例は 451例あつた．また同期間の結腸・直腸癌例は 209例で らち結腸・直腸癌によるイレウス例は42例でイレウス例 の約 $9 \%$ ，結腸・直腸癌例の約 $20 \%$ を占めている.

便秘, 下腹部痛又は腹部膨満感を主訴として来院し， 来院時全例に腹部単純 $\mathrm{x}-\mathrm{p}$ を掫つている. 診断では初診 時腹部単純 $\mathrm{x}-\mathrm{p}$ の大腸ガス像にて大多数の症例が診断さ れ，単純 x-p の診断価値が再確認された.

年令分布は30藏から86歳にわたり平均58歳で，病変部 位は S 状結腸が最も多く, 右半結腸飞も約 $1 / 4$ 名存在し た. 入院前病悩期間は，穿孔例，及び $2 ， 3$ の例外を除 いては下位消化管イレゥスを反映して，2週間から7カ 月と長いるのが多かつた。完全閉塞, 不完全閉塞, 穿孔 飞分けて，手術法，予後，合併症について梌討した，手 術法は一期的手術之二期的手術があり，大多数は一期的 手術を行ない,そのうち約半数は一期的切除を行なつて いた. 残り半数は人工肛門造設術, 腹腔内昒合術を行な つていた.

予後は $2 / 3 か ゙$ 軽快退院し， $1 / 3 か ゙$ 死亡退院して括り、イレ ウス状態にて来院する症例は, 病变が進行し, 全身状態 の悪いものが多い事ああり予後亚悪いものが多かつた。

合併症では全身状態の悪い高令者が多い事の影響で肺 合併症, 縫合不全, 㓣感染等の合併があり, 特に肺合 併症では若年者の 1 例を除き, 全例死の転㷌をとつてお り, 術後の全身状態管理の重要性を痛感した。

183. 回盲部捻転症を伴った Wilkie 症候群の一治駼 例

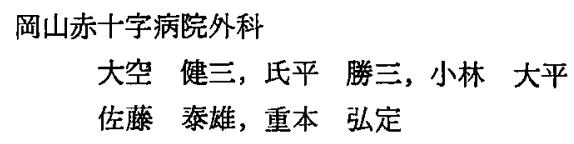

回盲部捻転症及び Wilkie 症候群はそれぞれ比校的稀 な疾患であるが，我々は最近雨者を合併せるイレウスの 1 例を経験した．患者は男子，12藏の頃から年数回腹部 
膨満と呕吐を来していたが，时粶位をとることによつて 治恣していた。17歳のとき同様に腹部膨満と呕吐などの イレウス症状を来し，肘㮏位にてす改善せず来院す、入 院時, 体格中等度, るいそうはなく, 晹雑音は軽度六進 していた，X線娭查では，大きな鏡面像を有する腸管の ルーブを認め, 注腸㭘査にては, 上行結腸中部より腸管 の狭窄があり，盲腸及び回腸へのパリウムの流入はな く, 回盲部捻転症の診断で開腹した. 胃十二指腸に異常

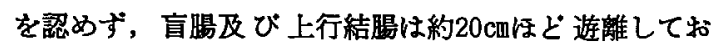
$り$, 回腸約 $140 \mathrm{~cm}$ ととに反時計方向に約 180 度捻転し ていたので，これを整復し，盲晹固定術を行つた. 術後 30 日目頃から再び腹部膨满と呕吐を来すようになり, 消 化管検查にて十二指腸第 $2 ， 3$ 部の払張と通過障害を認 めWilkie 症候群を合併していることがわかつた，肘膝 位にて症状は改善されるが完全に治疮しない為, 術後第 59日目に再閉腹した.十二指腸第 2,3 部の抎張とX線 像に一致する閉塞を認め同症を確翟し, 後結腸的に十二 指腸空腸側々吻合術を行つた. 更に中枢側回腸の高度な 掺張があり, 回盲弁付近の通過障害も認められたので, 回盲部切除回腸結腸端々吻合術も行つた。しかし症状は 改善されず, 消化管検査にて造影㘊は十二指腸空腸吻合 部を通過するす輸出脚へ流出せず，第 3 回目の手術を施 行した. 開腹時吻合部は開存していたので, 空腸側々吻 合術と胃掼造設術を行い，胃瘦より二重管を十二指腸空 腸吻合部を越して空腸へ留置す，術後は二重管よりの高 カロリー流動食火よる治療を経口摄取良好となるまで行 つた。な㧍ストログラフィンが術後腸管麻痷の治療に 有効であつた。

184. 教室に於ける晹管結節形成性イレウス14例につ wて

\section{日本医科大学第 1 外科}

藤平 威夫, 能谷 好正, 宮下 正雄 足立 憲治, 值原 忠良, 森山 雄吉 恩田 晶彦, 吉岡 正智, 清水 淑文 大川 共一, 三樹 勝, 代田 明郎

腸管結節形成によるイレウスは，その成立機転が複雑 なばかりでなく，数多いイレウスの中で極めて稀な疾患 であり，本邦に於ける報告例は僅かに65例を数えるにす ぎない，このうち教室に於いて経験した症例は14例で実 にその $21.5 \%$ 占めている.このうち 7 例は既に報告し ているが，その後の 7 例をす加えて一括報告するととも に本邦に於ける本症例の統計的観察を行つたので報告す る.
1）頻度：昭和10年 6 月より昭和50年 5 月迄のイレウ ス手術患者 1,177例（単純性 478例, 複雑性 699例)の 5ち，腸管結節形成イレウスは14例，1.2\%である。

2）性別，年令：本邦例では男子38例，女子25例（不 明 2 例) で, 男子に压倒的に多く，20歳代が 5 例，30歳 代が 4 例と若年者に多くみられている.

3）結節形成に関与する腸管の部位： $s$ 字状結腸と小 腸との結節形成が最も多いと報告されており，本邦65例 中48例を占めているが，教室例は 4 例で，他の10例は何 れる小腸相互間の結節形成によるすのである. 又同時に 腸管蹄俰の軸転を伴つた所謂軸転不通症の症例が多い.

4) 症状並びに診断：本症の症状経過は激烈かつ迅速 で，本邦例をる含め術前適確なる診断を下し得たすの， 及びそれを疑い得たるのは，小腸と S 字状結腸の結節形 成の教室例 2 例のみである，その他は何れす単にイレウ スと診断されているにすぎない。

5）治療成䌐：手術により結節を解除し得たもの10 例，腸管壊死を伴ない腸切除を行つたもの4例である が, 手術による死亡例は結節解除のみに終つた 21 歳, 男 子の小腸・小腸結節形成例 1 例のみで, 死亡率 $7.1 \%$ で ある. 本邦例についてみると，49例中13例が死亡し，死 亡率は $26.5 \%$ と極めて高い。

185. 诙着性イレウスの問題点と治瘭法 帝京大学四方外科

三重野寛治, 埜口 武夫, 竹崎 三立

長谷部正晴, 越川 宏一, 松尾 泰伸

四方 淳一

腹部外科領域における診断技術の向上とともに早期開 腹術の症例も増加する傾向にあるが，急性のイレウス症 状を主訴として入院し詳細な診断的時間の余裕のないま ま開腹せざるを得ない症例もしばしば遭遇するところで ある。一方日常容易に行われている閉腹手術後の合併症 としてのイレウス，とりわけ原疾患と無関係に惹起され る偭向のある癁着性イレウスは多くの外科医の関心のあ るところである.

我々は昭和 47 年以来, 本院及び関連病院の入院患者と 他施設からイレウスと診断されて入院した患者を含めて 52症例につき検討し分析してみた。内訳けは，手術症例 が32例でこのらち約30\%が癒着性イレウスの診断で開腹 手術を受けている．次いで尰瘍が原因によるイレウスが 19\%である.一方非手術症例群が19例で，このちち以前 何らかの原因で開腹手術を受けたものが16例と84\%を占 めており,ここです従来言われているように術後の疼着 
生イレウスが問題となつている，我々は術中に㽽着をい かに少なくするかの工夫を考光るととるに，再開腹症例 に拈ける腹曌内海着状態の検討も行つているのでこれも 併せて報告する。

186. 腸閉塞症と高セロトニン血症（特にその診断的 意般について)

横浜市大第 2 外科

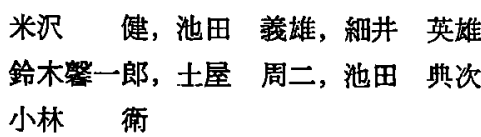

イレウスは我々外科医が日常よく遭遇する疾患であ り，またその病態生理については，数多くの研究がなさ れているが，甚だ多くの問題が残されて和り，その病態 る商確に猃断し得る方法恃未た見当たらない，Fineの エンドトキシンに関する研究が報告されて以来，イレウ スに护る,エンドトキシン拈よびる chemical Med iator としてのヒスタミン，七ロトニン，フセキルコリ ン, キニン, プラスミン等に関する研究加増加しつつあ る.そこで我々は血中セロトニンの測定がイレウスの診 断および治潦法選択の一助となり得るものと考え，イレ ウス患者78例について, 閉塞解除前後の血獎セロトニン 值を測定し，臨床症状，手術所見，術後経過と比較検討 した結果以下の知見を得た。治療前セロトニン值は，(1) 手術を必要とした症例は非手術例に比して高値を示し た。（2) 手術例に沶いて大腸閉塞よりむ小腸閉塞の方が 高值を示し，小腸閉塞においては上部閉塞よりも下部閉 塞の方が高値を示す．3）腸管循環障害のある症例は循 摆障害の無い症例より高い，(4) 腸管抬張の著明な症例 は高值を示す．治療後のセロトニン值の変動をみると， (1) 非手術例では抗生物質投与，イレウス管による腸内 容吸引により正常値に復した。(可手術例においては術 後48㭙間〜72時間で正常值にもどる．（3) 術後イレウス 状態が邆延する症例ではセロトニン值が正常值にもどら ない。

以上の結果よク，イレウス患者の血中セロトニン値を 测定することは，腸管の循環障害の有無および腸の閉塞 部位の診断に役立つとともに予後の判定にも有用である と考光る．今回は症例を供覽しつつ併せて，以上の結果 について述へたい。

187. イレウスの臨床的考察

富山市民病院外科

広瀬 道郎，広野 襀介，太田斉

奥田 害三，沢崎 邦広
当外科飞打いて，昭和43年 3 月より昭和50年 3 月迄 に，手術を䈇行さたイレウス症例は90例であり，このう ち病型別には，閉鎖性イレウスが60\%，絞扼性イレウス が37\%で，部位別では，小腸が大多数を占めている，60 歳以上の高令者イレウスは，25例で，原因別にみると， 我々の施設では，㷋症によると思われるすのが多い，既 往の開腹衍に関連して発病した術後イレウスは，40〜59 歳で最も多く，その開腹術では，胃十二指腸手術後イレ ウスが，一番多々，従来多いとされた虫垂炎手術後のる のは，比較的少ない，又イレウス術後 2 週間以内の手術 死亡は，8例であり，これらの症例について，手術に至 る迄の期間, 脱水の有無, 緊機能, 刵機能, 心電図, 酸 塩基平衡等に付き梌討し，こ5いつた症例では，入院 時既に，重症脱水が著明で，腎不全状態を是し，高K 血症, 乏赭が認められ，従つて輸液に際しては，充分の 配虑が必要で，Kの投与には慎雷でなければならないこ と, 又, 肝機能障害が恋められることが多く，これは一 次的腸切除に伴ら程命不全とその為の手術時間の延唇に

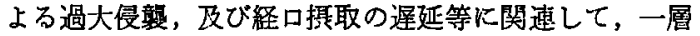
術後管理を複雑にすることとなり，症例によつては，過 大唚鐜を避け，腸瘦造設による待期的根治術我考虑され るべきことを強調する。

188. イレゥスの治療，特に 5 日間以上吸引療法を続 づけた症例の検討

日本医科大学第 2 外科

馬越 正通，横須賀 稔，楠本 春应

横須賀 政，啮谷 男，飯島 位夫

野中達也，片岡一朗

イレウス，特に術後瘾着性イレウスに対し，われわれ は長年に渡つてイレウス管による吸引療法を行つてお り，その結果についてしばしば報告してきた。

教室の経験では，イレウス管による吸引開始後，3日 以内に解除または不解除の決定がなされている場合が多 かつた．その間, 全身状態, 腹部所見, 経時的に撮影し た腹部単純レ線所見及びイレウス管の進行状態などによ り䋊過を鎮重に観察することによつて，吸引療法続行の 適否を決定して扰り，手術の時期を逸しない様に注意し ているのであるが，症例によつては不手術的に解除可能 な所見を呈しているにもかかわらず，なかなか解除 せ ず，躊踷しながらも吸引療法を続づけた症例も少なくな い. 特にイレウス再発例で, 前回に不手術的に解除して いる症例では，また不手術的に解除出来得る可能性が高 いと考えており，これらの症例に対しては，特に積極的 
に吸引療法続行の態度をとつているが，この中で最近す でに 2 回不手術的にイレウスを解除している症例で，今 回も不手術的に解除可能な所見を呈していたため吸引療 法を続づけたが，7日目に解除不能を診断し開腹手術に 踏み切つたところ閉塞部位は强固な㾌着で, 癒着腸管の 内胿には潰瘍を形成し, 瘦痕性の狭窄を来たし，この所 見からは到底不手術的に解除不能と考えられた症例を経 験した。

教公のでは，10日間も吸引療法を続づけ解除に成功し た症例や，その時点で手術に踏み切つた症例す释験して いるが，今回は，5 日間以上吸引療法を続行した症例 36 例 (解除成功 21 例, 不成功15例) について, 閉塞の型, 部位及び閉塞状態などを検討し，イレウス管による吸引 療法の適否について再検即してみた。

189. 盲腸非特異性溃瘍15例の検討 横浜市立大学第 2 外科

$\begin{array}{lrl}\text { 池田 } & \text { 典次, 鳰田 私, 松田 好雄 } \\ \text { 西山 潔, 竹村 } & \text { 浩, 洲崎 兵一 } \\ \text { 土屋 周二 } & & \end{array}$

演者らは，10年来，大腸に癌之誤られるような炎症性 睡瘤を形成する疾患を大晹非特異性炎症性連瘵と総称 し，収集してきたが，その大部分の症例は病変部に非特 異性潰瘍を形成していることから，いわゆる大腸非特異 性潰济例ということができる.今回は，これらの症例あ るいは別途に大腸非特異性潰瘍として収集した症例中， 特に盲腸の侵された15症例に対し，臨床的立場から検討 そ加えて報告する. 症例は男 8 例，女 7 例で, 霍患年令 は10〜64歳である. 15例中13例 (A 群) は1.0×1.0cm径 以上の比較的大きく，乙か子慢性消化性溃瘍酷似の深達 性溃湯を示し，他の 2 例（B 群）は $1.0 \times 1.0 \mathrm{~cm}$ 径以下の 多発性小潰場を示している．A群の主症状は，腹部隀瘤 の触知のみを訴えた 1 例を除き，他はすべて右下腹部の 自発痛, 圧痛である. また過半数の症例において初診時 に右下腹部腫瘤が繦知されている.虫垂切除の既往が $2 / 3$ の症例にある. 術前に intestinal Behçet と考えられた 1 例を除き, いずれの例も開腹時に回盲部癌の疑いで回 盲部切除 (11例) または結腸右半切除（2例）が行われ た。 B群に属す 1 例 (37歳，女）は，下血を主訴とし， A群のそれと異なる浅い多発性の急性小溃湐を示し，他 の 1 例 (44歳，女）は，発熱と右下腹部痛を主訴とし， 衍前血中好酸球最高65\%を示した多発性小漬瘍例であ る. 第 2 例の好酸球增多は回盲部切除後正常に復した。 盲晹非特異性潰晹の術前診断は，まず不可能であるが，
回盲部の癌，結核との鑑別が問題である．外科臨床上, 重要なことはA群の術後に 4 例の再発例を経験している ことで，他の本邦報告例をる勘案し，本邦の盲腸非特異 性潰激は，欧米で “simple ulcer”などとして報告され， ているものと，かなり異なつた性質を備えていると思わ れ，切除䉇困などについてる，本邦独自の考慮が払われ る必要があると考える。

190. 泒立性直腸潰癔の3 例 和歌山県立医科大学消化器外科

榎本 光伸, 勝見 正治, 梁 貴容 浦伯三，勝部 有二，殿田 重彦 菻本 悟一, 和田 信宏, 松本 孝一

大腸に発生する良性の潰湯性病変としては, 結核, 潰 场性大腸资，クローン氏病等が代表的であるが，近年単 純性非特異性溃湟が注目をあびるようになり，本邦に於 てもいくつかの症例が報告されるよらになつた。我ふは その中です稀である直腸限局型の 3 例を経験したので報 告する. 症例1.45藏男性で便秘を主訴とし来院, 入院 4 日目下血あり，直腸鏡にて，7〜8 cm口側の直腸前側 壁に単発の潰瘍あり，狭窄を認めたので，人工肛門造 設，一時潰瘄の消失を認めるも，術後 6 年目の現在再発 をみる．症例2．59歳男性で突然大量下血を来し，直腸 癌の疑いにて来院，内視鏡にて，10 cm直腸側壁に単発の 潰湯を認めた。病理組織診断は, 孤立性直腸溃湟で，保 存的に治療, 現在出血等は認められない. 症例3.71歳 男性で，下血を主訴とし来院，5cm直腸前壁に潰湟を認 め，生検するに単純性溃堭であつたが，臨床的に悪性垁 患を否定しえず, 直腸切断術施行. 術後経過良好で, 現 在再発は認められない，以上我々が経験した 3 例を報告 したが，欧米及び本邦報告例と比すれば，自験例及び， 本邦例は男性が多く, また, 年令は欧米に比し, 高令者 が多い，主訴は，下血，粘液排出，下腹部痛が主なるの で，特に下血例が多く，大量下血を゙来たす例すある。溃 湯は単発例が多く, $7 \sim 10 \mathrm{~cm}$ 直腸前壁にあり, 浅いるの と特徵つけられているが，自験第 3 例は，深くて，結腸 の非特異性潰瘍に類似していた，本症の病因はいまだ不 明で，治療法も画一的でないが，非常に難治性であり， 我々の例で, 完治し得たのは，第 3 例のみで, 他は再発 をみた．欧米や本邦の報告に於ても，再発例が多く，唯 一の根沿術は, 直腸切除術と考支ている.

191. 監別困難な右側結腸谈の 1 例 東京都立豊島病院外科

并上 勇, 河井 文健, 天羽 達郎 


\author{
大竹 弘司, 唐木 一守, 川越 常盤 \\ 森 正秨 \\ 同病理 \\ 中村 俊彦
}

橋本 重夫（現近大第 2 病理教授）

溃疸性大腸炎の1型として取扱われてきたいわゆる右 側結晹炎は肉芽腫性大腸炎との異同をめぐり，な扣議諭 が多い. 病理学的に鑑別困難な unclassified case の頻度 は5〜10\%といわれ，われわれる最近肉芽腫性大腸炎に 酷似するがむしろ潰㾤性大腸炎と考えたい複雑な病像を 呈したいわゆる右側結腸炎の 1 例を経験したので症例を 供覧して批判を仰ぎたい，症例は20歳の男性で横行結腸 癌の診断で結腸右半切除が施行された．開腹時右側結腸 及び横行結腸は膿苔を有する大網に完全に被覆され小児 頭大の腫瘤を形成し巨大な膿湯が隣接していた，切除標 本の結腸壁は炎症性に肥厚著しく病変の強度な部では 3 cnkb達し肉眼的にも明膫な intramural abscess がみら れた. 内县には極めて奇異な mucosal tag 及び迷路状の mucosal bridge が混在し殆えど内腔を閉塞して特り，溲 疸を認める部の怢窄は極度であつた。検鏡的には潰瘲よ り連続する fissure がみられ多数の膿瘍を形成し，炎症の 強度のところでは筋層の欠如も認められた。 fissure 周囲 には異物巨細胞がみられるが sarcoid 様肉芽連の形成は ない. mucosal tag, mucosal bridge 基部には新しい下掘 れの小潰瘍を喼め周辺には crypt abscess む散見された。 これらの病变は右側結腸より連続性に横行結腸半ば迄27 cmにわたつていたが，回腸末端，下部結腸，直腸，肛門 は病変を免がれていた。本例における transmural な病 変は肉芽腫性大腸炎の印象を強くするが，潰煌性大腸资 に準ずる所見す併存していると考えられ，われわれはこ の transmural の変化は潰瘲性大腸炎の slow-microperforation によつて惹起された二次的なるのであろうと推論 している.なお本症例に打いては術後 8 力月現在再発の 兆はない.

192. 潰瘍性大腸炎の手術一とくに直晹温存術式の適 店一

\section{横浜市立大学第 2 外科}

竹村 浩, 松田 好雄, 过仲 康伸

池田 典次, 土屋 周二

潰瘍性大腸炎に対する手術は大腸全摘出兼迴腸肛門造 設術があつとも根治的な標準術式とされ，直腸温存術式 は長期経過後の再発などの点でこれに反対するすのむあ る.しかし我々は適俯の撰択，手術々式の改善，術前術 後の管理の向上, 戏存直腸の病変に対する長期の観察と
処㯰などによつて, 直腸温存術式の安全性と根治性を高 め,なるべく本術式を採用している。

教室に打いて最近手術された 8 例中 4 例が本術式によ るものであり，術後経過年数は最長 1 年と短いが全例と も術後程過 は良好であり, 順調に社会復㷌も行なわれ た. 術後, 時に少量の出血がみられる昜合もあるが, 再 然を来たした症例は皆無であり，温存された直腸の内視 鏡所見，生検所見も短期間に改善されている。

本法適応の撰択に際して術前の諸検査すなわち注腸バ リウム, 内視鏡お゙よび生検組織検查は重要である。レ線 上直腸に著るしい狭窄户径, 長さの短縮が諗められる場 合，内視鏡的に溃湟，出血を伴う急性活動期の場合，ま た組織学的に直腸全層にわたる高度の急性炎症所見の認 められる場合以外は本法の適応となるものが多いと思わ れる. 術前の保存的治療により直腸所見の改善をみるも のは本法の適応となる。これらの点は切除標本の検索か らすらかがわれる。

193. 救命し得た激店型溃痬性大腸炎穿孔の 1 症例 日赤医療七ンター幕内外科

竹中 文良, 河野 正賢, 渡辺昇

三国 和雄, 高野 章, 大和田晴彦 味八木保雄, 戸井 則夫, 楠本 英二 向井 良太, 森田耕一郎, 幕内 精一

急性激症型漬瘍性大腸炎の三大合併症は, 出血, 中毒 性払張, 穿孔である. 特に結腸穿孔は重篤であり, 中で も汎発性腹膜资を合併したものは著しく予後が悪い。

我々は最近, 全結腸型溃瘍性大腸炎加療中盲腸部にて 穿孔，沉発性腹膜炎を併発した症例に対し，結腸全剔， 回腸瘦造設，残存直腸粘膜を電気メスによる凝固止血を 行い，2 カ月間の中心静脈栄着を併用して治痹せしめ得 たので報告する．

患者は29葴の主婦で, 発病直後より大量の下血, るい

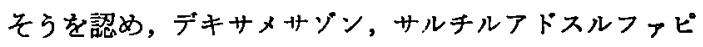
リン投与にて一時改善した。発病 3 カ月目に中毒性払張 を来し, 外科治療方針に变更, 計画中盲腸部にて穿孔。 穿孔後 6 日目に開腹した. 腹腔内には大量のガス膿汁と 肝前面より腹腔全面に及ぶ黄褐色污泥状の厚い膿苔を認 めた．盲腸部穿孔による汎発性腹膜炎と䛦断, 結腸全剔 回腸㾇造設術施行, 腹垫内洗浄を繰返し,ドレナージを おいて閉腹したが，残存直腸粘膜よりの大量出血持続， 止むなく電気メスを用い，経肛門的に直腸粘膜を焼却， ようやく止血せしめた。

術後, 腹部創よりの持続出血, 手術創の哆開, 低蛋白 
血症, 電解質アンバランス, 敗血症, 尿路感染症, 肝炎 等の合併をみたが，2 カ月間の中心静脈栄鵄を合む，合 垪療法にて治瘾せしめ得た。

194. 大腸クローン病の 6 例

岐阜大学第 1 外科

腹田 甚三, 安藤 充晴，林 淳治

岩島 康敏，鬼束 惊義，松原 長樹

多羅尾 信, 後藤 明彦

われわれは最近10年間に大腸クローン病の 6 例を経験 したので報告する .

発生部位は回盲部 2 例, 回腸扰よび結腸 1 例, 結腸全 体にわたるるの 1 例, 直腸飞限局するるの 2 例である. 年令は15歳より61歳までであるが，そのうち 5 例が 40 歳 以下で，比較的，若年層に発生している. 性別は男・女 とむと 3 例で性差はない，病悦期間は 1 カ月より 2 年で あるが，そのらち 4 カ月末満が 3 例ある. 症状は腹痛，

下浰, 排便困難, 下血, 腹部腫瘤であるが，そのらち腹 痛が 3 例あり，腸狭窄によるものである，術前のX線検

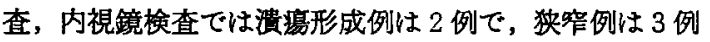
であり，生検を実施した症例では，粘膜上皮の浮腫，細 胞浸潤を認めた。外科的治療は全例飞実施し，結腸右半 切除 4 例, 直腸切断およブ人工肛門造設 1 例, 直腸扩よ び S 状結腸切除，貫通法に上る肛門括約筋保存術 1 例で ある.衍後の経過は再発例が 2 例であり，1 例は15歳の 女子で結腸右半切除後 2 年で, 同吻合部再発し, 再手 術を実施したが 3 年後に死亡した，他の 1 例は 25 歳の男 子で回腸部分切除後 1 年で，回腸末端より結腸にかけて 再発し，再手術により，術後 4 年で経過良好である。 そ の他の 4 例は術後 1 カ月から 4 年で健在である.

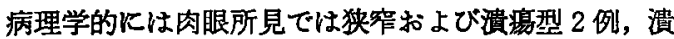
晹型 2 例，狭乍型 2 例であり，數石状外観を呈したもの が 3 例である. 組織学的には全例に大小の謴煌を認め， 結腸壁は肥厚し、リンパ球および巨細胞の浸潤，結合織 線維の增殖を認めた肉芽腫を形成しているが，乾酪巣は 認めない。このうち 4 例結核菌染色を実施したが結核 菌は認めていない.

以上の应例について検討し，術前の診断および潰埸性 大腸炎扰よび大腸結核との鑑別についてものべる.

195. 大晹ポリープと癌との合併例の検討 信州大学第 2 外科

野村 節夫，若林 正夫，小池 綏男 中藤 刞義, 飯田 太, 降旗 力男

最近20年間飞教室で取り扱つた大晹癌は160例で，
このうちポリープを合併した症例は13例，8.1\%にあた る.これらの症例について，癌とポリープとの位置的関 係を検討した。

まず，衍前にポりーブの合併を診断し得た症例は，わ ずかに 3 例で，他はすへてて大腸癌の診断のるとに手術を 行ない, その際癌の近傍, または遠谝の部に大腸ポリ 一プを発見したものである.そこで，ポリープの発生部 位を検討すると，上行結腸から S 字状結腸に和よぶもの が 1 例，下行結腸のみのすのが 1 例， $\mathrm{s}$ 字状結腸から直 腸におよぶものが 3 例で，直腸汇限局するものが最も多 く8例にみられた。 また，癌とポリーブとの相互の位置 的関保をみると，ポリープが大腸の広範团にわたつて存 在する 4 例では，いずれも癌はポリーブの肛門側飞喼め られた。またポリープが直腸だけ限局した定例でも 8 例中 6 例飞打いて癌はポリープよりも䀴門側飞認めら れた。他の 1 例では，逆にポリーブより口溉に癌がみら れた。 その他に，直腸に限局した多発性ポリープの 1 例で，初回入院時に，adenomatous polyp と確認された が，6年後にポリープの最す肚門側寄りに癌の発生をる た.これらの所見は，ポリポージスの癌化関与する要 因の一つを示唆するすのと思われる.

以上の成績に，さらに，家族性ポリポージスの 4 例を 加えて，大腸ボリーブと癌の関俰について考察を試みた W.

\section{Gardner 症候群の一家系について} 熊本市立熊本市民病院外科

長尾 和治, 春木 哲哉 松本 忠, 近藤 浩幸

同中央検查室松本 英世

腸管ポリポージスはその悪性变化と家族性発生および 全身的症候群との関連で外科臨床上注目されている。私 達は比較的化ま机とされている Gardner 症候群の一家 系を発見したので報告する。.

本症候群の発見の端緒となつた21葴男子の症例は，(1) 十二指腸以下直腸にいたる全腸管に多数のポリーブを認 め, その一部の悪性変化と推定される横行結腸癌のため に死亡した. (2) 頭骨の骨腯を認めた. (3) 腹壁と両下 肢とに epidermal cyst を5コ証明した。さらに14䠞の 時に筲部の手拳大の軟かい腫瘤摘出術を受けている。こ

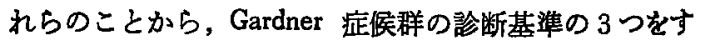
べて満足する完全型と診断した。

患者の実兄は 2 人共何らの自覚症状を示していなかり たが, 注腸透視と直腸検查の結果, 直腸と大腸に大豆大 
から示指頭大のポリーブを多数認めた．また 33 藏の長兄 はレントゲン写真で頭骨に骨嗹を認め，聑幹の皮下の 6 この epiderraal cyst を摘出した. したがつて本症候群 の完全型である．28藏の次兄は下靧骨に骨腫を証明した が皮下の良性腫場は証明されず，不完全型である。

この兄弟の母親は胃癌のために53歳で死亡している. 父親の実妹 2 人には腸管にポリープは認めなかつた。

しかし 前述の患者とその実兄 2 人と共に，父親が直 渴癌として46歳で死亡していることは，Gardner 症候群 と家族性ポリポージスとの関連を研究する上で興味ある 家系であつた。

また死亡した患者は大晹ポリポージスたけけではなく， 十二指腸以下の全腸管に多発性のボリープを認めたこと る，今後の検討を要する本症例の特徽であると考光る．

197. 家族性大腸ポリポージスの 2 家系 和歌山労災病院外科

家田 勝幸, 大沢 祐三, 中山 一成 染 貴容, 一宮 源太

和歌山県立医科大学消化器外科 森本 悟一, 浦 伸三, 勝見 正治

最近われわれは家族性大腸ポリポージスの 2 家系 5 症

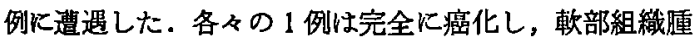
啺等を付䯣していた。

症例1. 40 藏古。下峲, 便秘で来院. 右腋窩, 右肩甲 部に軟い聥瘤あり．注腸，colonofiberscopy にて大腸全 体に無数の polyp を認め, 直腸上部に悪性化を思わしめ

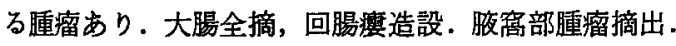

病理組織 polyps. 旅萵の腫瘤は epidermal cyst. その後のレ線検查 で上頼に骨腫を認めた。

症例2. 16 葴早及び症例3.11歳, 合，共に症例 1 の 子で, 注腸にて大腸全体に多数の polyp 摁めるが, 愁 訴もなく内視鏡検查の協力は得られておらす，観察中で ある。

以上が同一家系で, 以下第 2 の家系である.

症例4. 28藏古. 腹壁缠瘤と下血飞て来院. 左下腹 部, 右悸助部化硬い尰瘤あり。注腸, colonofiberscopy にて大腸全体に無数の polyp 経肛的 polypectomy. 盲腸 から上行結腸の polypは小なさく，数も比洨的少いた め, 大腸全亜摘, 盲腸で人工肛門造設. 下腹壁腫瘤摘出. 病理組織仙 adenoca. (直腸下部) and adenomatous polyps. 腹壁腯瘤は desmoid. 下䫇の panoramic X-ray で骨 連様変化を認めた．胃〜小腸に polyp は認めなかつた。
症例5. 32歳早 (症例 4 の姉). 注腸, colonofiberscopy にて大腸全体に多数の polyp. 悪性所見を認めないため 簃重観察中. 下䫑へ panoramic X-ray で骨連様变化を 認めた。

以上 2 家系 5 症例の家族性大腸ポリポージスを経験し た. 家族性大腸ポリポージス Gardner 症候群とが独立 した疾患であるか否か議諭されているところであるが症 例 1 および 4 は各々，宇都宮らの完全就よび不完全Gardner 型家族性大腸ボリポージスと思われる.

198. 内視鏡的大腸ポリベクトミーの検討 東京女子医大消化器病センター消化器外科 青木 暁, 中村 光司, 小叹知一郎 長谷川利弘, 鈴木 博孝, 矢沢 知海 浜野 恭一, 遠藤 光夫

同消化器内科

長 迴紘, 中江 道義, 佐々木宏晃 竹本 忠良

平塚病院生沢 啓芽

Surgical endoscopy として polypectomy はその代表的 なものの 1 つあでり, 内視鏡的 polypectomy は診断てけ でなく、治療の画からもその臨床的における意義が大き い. 我々は第15回日本消化器病学会秋季合同大会のシン ポシウムにて既に報告したところであるが，消化器病せ ンターと执いて大腸の polypectomy は自鈳例60例計68 である。これを詳紐に検討すると，部位別では S 状結腸 が一番多く36コ（52.8\%）, 次に直腸 17 (25\%),下行結 腸 6 二, 上行結腸 5 二と盲腸, 横行結腸の各 2 である. 組織型では腺腫性ポリーブが一番多く47コ（69\%), 次に 特異性ボリープ13 こと早期演 5 コ，過形成ポリープ 2 ב と若年性ポリープ 1 コを経験している. ポリープの型別 は亜有茎性 29 コで最す多く, 次に有茢性 24 , sessiletype 15コである. 大きさをみると最小のるのは径 $4 \mathrm{~mm}$, 最大径では28m. また最大径の頻度別をみると, 径 6〜

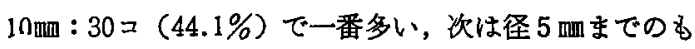
の15=(22\%), 径11 15m䀦が 9 コ, 16〜20血：6コとな つている. polypectomy 後の回収は注とんと吸引回収を おこなつており，68回中わずか 1 回の回収失敗がみられ た。合併症では出血と穿孔が考えられるが出血は生検程 度の出血であり，穿孔は1例も認めていない，以上我々 の自験例60例計 68 コの polypectomy を詳細に検討し, 若干の考察を加えて報告する.

199. 大晹癌手術例の統計的観察 岡山済生会総合病院 